tuần thứ 120 sau phẫu thuật ung thư phổi không tế bào nhỏ ở những người không hút thuốc và đã cai thuốc là $60-70 \%$ so với chỉ $25 \%$ ở những người tiếp tục hút thuốc. Có nhiều giải thích cho sự khác biệt này bao gồm cả sự gia tăng biến chứng từ điều trị, tái phát ung thư và sự xuất hiện các khối u mới. Cai thuốc sớm hơn thì tốt hơn, với mỗi tuần cai thuốc sớm hơn sẽ giảm nguy cơ biến chứng sau phẫu thuật thêm 19\%.

Cai thuốc lá cũng giúp cải thiện đáp ứng của bệnh nhân ung thư phổi với điều trị hóa chất và xạ trị. Hút thuốc lá ảnh hưởng đến chuyển hóa thuốc. Thuốc ức chế thụ thể yếu tố tăng trưởng biểu bì (EGFR) erlotinib được chuyển hóa ở mức độ cao hơn ở những người hút thuốc do sự kích thích của enzym cytochrome P450, CYP1A1/1A2. Những người hút thuốc mắc ung thư phổi không tế bào nhỏ có ít đột biến EGFR kích hoạt hơn và những thay đổi gen điều khiển anaplastic lymphoma kinase làm giảm khả năng đáp ứng với các thuốc ức chế EGFR. Một nghiên cứu trên 83 bệnh nhân mắc ung thư phổi không tế bào nhỏ được điều trị xạ trị, hút thuốc lá là một yếu tố nguy cơ độc lập cho sự tiến triển viêm phổi sau xạ trị và nhiếm trùng phổi. Tỷ lệ sống trung bình và sống sau 2 năm cũng lâu hơn ở những người không hút thuốc. ${ }^{21}$ Cai thuốc lá cũng giúp cải thiện chất lượng cuộc sống và bậc thang thể trạng ở những người hút thuốc mắc ung thư phổi.

Mặc dù việc cai thuốc đóng vai trò rất quan trọng đối với những người hút thuốc mắc ung thư phổi, tuy nhiên có khoảng $10-13 \%$ bênh nhân vẫn tiếp tục hút thuốc ở thời điểm 6 tháng sau khi chẩn đoán ung thư phổi. Điều trị cai nghiện thuốc lá cho những bênh nhân mắc ung thư phổi cần kết hợp tư vấn thay đổi hành vi với thuốc điều trị hỗ trợ cai nghiện thuốc lá và theo dõi thường được kểt hợp với các lần thăm khám điều trị bệnh, nội dung tư vấn được thiết kế cụ thể để tăng cường sự tự tin cai thuốc, giảm trầm cảm, giúp bệnh nhân tăng khả năng cai thuốc lá thành công.

Tóm lại, hút thuốc lá chủ động và thụ động là nguyên nhân chủ yếu gây ung thư phổi. Người hút thuốc lá có nguy cơ bị ung thư phổi cao gấp 15- 25 lần so với người không hút. Hút thuốc lá càng nhiều năm, số lượng thuốc lá hút càng nhiều thì nguy cơ mắc ung thư phổi càng lớn. Việc cai thuốc lá giúp giảm nguy cơ phát triển ung thư phổi, giảm nguy cơ biến chứng sau phẫu thuật ung thư phổi, cải thiện đáp ứng của bệnh nhân ung thư phổi với điều trị hóa chất và xạ trị. Vì vây cần điều trị cai nghiên thuốc lá cho tất cả những người nghiện thuốc là và những bệnh nhân mắc ung thư phổi cũng như các bệnh khác liên quan thuốc lá.

\title{
TÁC HẠI CỦA KHÓI THUỐC LÁ VớI HỆ HÔ HẤP
}

\section{TÓM TẮT}

Mặc dù phổi là bộ phận của cơ thể được bảo vê bởi hể thống miễn dịch chung và bởi cơ chế tự bảo vể tại phổi, nhưng vẫn bi tác động của các chất độc hại có trong khói thuốc lá và tự môi trường. Tác hại của khói thuốc lá tới nhiều bộ phận của cơ thể và gây nhiều bệnh lý nguy hiểm đến tính mang. Ngay tại phổi, 2 bệnh hay gặp có liên quan đến thuốc lá là ung thư phổi và bệnh phổi tắc nghẽn mạn tính. Đây là 2 bệnh trong nhóm nguyên nhẩn hàng đầu gây tử vong trên toàn thế giới.

\section{SUMMARY}

\section{THE HARMFUL EFFECT OF SMOKING ON} THE RESPIRATORY SYSTEM

Even though being protected by genetically immune system and itself, lung is damaged by toxics in smoke and others from enviroments. Smoking can cause serious harm to all the body and produce many dangerous diseases. In lung, 2 diseases - lung cancer and chronic obstructive lung disease are closely concerning to smoke and being in the leading causes

\section{Đinh Ngoc Sỹ \\ Tổng hội Y học Việt Nam}

of death on the words.

Key words. Harm, smoking, lung cancer, COPD

\section{I. ĐĂT VẤN ĐỀ}

Như chúng ta đã biết, thuốc lá là một sản phẩm được dùng trong đời sống của loài người từ rất xa xưa. Trải qua nhiều thế kỉ, cùng với sự thay đổi của khoa học- công nghệ cũng như nhu cầu cuộc sống, khiến cho thuốc lá đã thay đổi không ngừng về chất lượng cũng như chủng loại, mẫu mã cũng như hình thái sử dụng. Mặc dù hiểu biết của con người về những tác động có hại của thuốc lá đã rõ ràng, song thuốc lá vẫn tồn tại như một phần không thể thiếu trong cuộc sống xã hội. Tại sao vậy? Có 2 lí giải cho sự tồn tại đó. Trước tiên phải nói đến đó là nhu cầu của người sử dụng thuốc lá do một số chất gây nghiện có trong thành phần khói thuốc lá (nicotin) khiến con người lệ thuộc vào nó. Thứ đến là do nguồn lợi khổng lî̀ mang tới từ ngành 
công nghiệp thuốc lá. Sự gặp nhau của 2 lí do này khiến cho thuốc lá-măc dù đã biết là có hại tới sức khỏe con người- vần tồn tại mà chưa thể nào khắc phục được.

Tác hại của thuốc lá tới sức khỏe con người trên hầu hết các chức năng sống của cơ thể. Bởi lẽ khói thuốc lá cùng với một số chất trong hơn 7000 hóa chất chứa trong nó đã được đi vào quá trình chuyển hóa của cơ thể sống ${ }^{(1)}$. Một khi đã vào chu trình chuyển hóa, chúng sẽ tác động lên toàn bộ cơ thể, không trừ một chức năng sống nào, không trừ một bộ phận nào của cơ thể. Trong khuôn khổ bài này, chúng tôi muốn khu trú vào hệ hô hấp bị ảnh hưởng ra sao bởi thuốc lá.

\section{SƠ LƯỢC V'Ê CẤU TRÚC CỦA CƠ QUAN HÔ HẤP}

Suốt từ mũi xuống tận phế nang của phổi là một hệ thống liên tục về giải phẫu và đồng bộ về chức năng. Điều quan trọng quyết định về chức năng cửa đường thở là sự tôn tại nguyên vẹn về giải phẫu cùng cơ chế tự bảo vệ của nó. Ǹgoài hệ thống miễn dịch bảo vệ chung của cơ thể thì phổi còn được tự bảo vệ bằng phản xạ ho, khạc và hệ thống biểu mô niểm mạc của chính mình. Niêm mạc gồm có lớp biểu mô trụ giả tầng có lông chuyển, cùng với dày đặc các tuyên tiết nhầy phế quản (Hình 1). Hệ thống lông chuyển và tuyến nhầy phủ gần toàn bộ niêm mạc đường thở. Hệ thống lông chuyển và chất nhầy do các tế bào tiết ra làm ẩm đường hô hấp và tham gia vào cơ chế tự bảo vệ của phổi(2)(3). Các phế nang chỉ được lót bởi lớp biểu mô rất mỏng gọi là biểu mô hô hấp mà không còn hệ thống lông chuyển. Vách phế nang có một mạng lưới mao mạch dày đặc, tại đây diễn ra quá trình trao đổi khí (Hình 2).

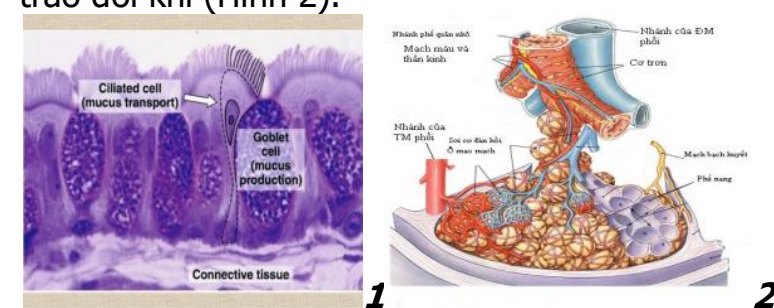

Hình 1. Biểu mô niêm mạc phếquản.

Hình 2. Túi phếnang và mao mach

Tế bào tiết nhầy sẽ tiết ra dịch nhầy phế quản, làm ẩm đường thở và cố định các hạt bụi, tác nhân có hại (vi khuẩn, vi rút...) từ không khí hít vào sau đó được hệ thống lông chuyển vận chuyển theo hướng từ trong ra ngoài, nhịp nhàng, đồng bộ từ phế quản nhỏ đến phế quản lớn và nhờ động tác ho, khạc để tống ra ngoài.

Biểu mô niêm mạc đường thở và các thành phần trong phế nang là hai cơ quan "đích" mà khói thuôc lá tác động. Các chất độc hại và chất có tính chất hạt sẽ làm cho hệ thống lông chuyển bị tổn thương, làm phì đại và tăng sinh tuyến tiết nhầy, làm dầy vách phế nang do cơ chế viêm không đặc hiệu mạn tính, làm tổn thương các tế bào (đại thực bào phế nang, tế bào phế nang typ 2...) dẫn đến rối loạn hệ thống tự bảo vệ và trao đổi khí của phổi - nguyên nhân sâu xa của một số bệnh hô hấp liên quan đến thuốc lá.

\section{KHÓI THUỐC VÀ CÁC CHẤT CÓ TRONG KHÓl THUỐC:}

Khói thuốc lá có chứa rất nhiều chất độc hại cho người hút và ngay cả cho người không hút (hít phải khói thuốc lá). Trong hơn 7000 chất có trong khói thuốc lá, ít nhất có khoảng 250 chất gây hại cho sức khỏe, gồm cả hydrogen cyanide, carbon monoxide, and ammonia ${ }^{(1)}$.

Các chất độc hại trong khói thuốc lá sẽ phá hủy biểu mô phế quản, làm rối loạn vận động lông chuyển của tế bào niêm mạc phế quản, làm tăng tiết nhầy của các tuyến, kích thích bạch cầu đa nhân giải phóng men tiêu protein, gẩy viêm mạn tính phế quản. Hệ thống lông chuyển bị đứt, gãy, vận động khổng đồng bộ. Trên kính hiến vi điện tứ, người ta quan sát thây những mảng lông chuyển bị xoắn vặn , đẩy dạt xuống giống như thảm lúa bị gió xoáy lốc, mất hướng chuyển động nhịp nhàng. Các tế bào hình đài tăng sinh, phì đại, tăng tiết nhầy và thành phần hóa học của chất nhây phế quản bị biến đổi, làm thay đổi độ dính nhớt, khiến nhiều đờm nhưng khó khạc. (4) Các tổn thương đó làm dầy thành phế quản, làm lòng phế quản hẹp lại (chỉ số bề dầy của tuyến phế quản/bề dày thành phế quản tăng (chỉ số Reid bình thường $=0,4$ ). Những rối loạn đó là cơ sở cho hàng loạt rối loạn bệnh lý có thể xảy ra với bộ máy hô hấp

\section{MộT SỐ BỆNH CỦA HỆ HÔ HẤP CÓ LIÊN QUAN ĐẾN KHÓI THUỐC}

Có thể nói khói thuốc lá cùng với nhiều hóa chất độc hại sẽ kích hoạt hàng loạt cơ chế phát sinh nhiều bệnh lí mạn tính có liên quan đến thuốc lá, song hai bệnh hay gặp nhất và gây hậu quả nặng nề nhất, đó là:

- Ung thư phổi. Khói thuốc lá là yếu tố nguy cơ đâu tiên, tại Mĩ có tới $80-90 \%$ tỷ lệ tử vong do ung thư phổi có liên quan tới thuốc lá. Những người hút thuốc lá mắc ung thư phổi hoặc chết do ung thư cao gấp 15-30 lần so với người không hút. Trong số 250 hóa chất có hại trong khói thuốc lá, có ít nhất 69 loại có thể gây ung 
thư, trong đó phải kể đến một số chất như Acetaldehyde, Aromatic amines, Arsenic, Benzene, Beryllium, Ethylene oxide, Formaldehyde ${ }^{(5)}$. Tỷ lệ mắc bệnh có liên quan mật thiết tới mức độ và thời gian hút. Thời gian hút càng lâu thì nguy cơ mắc bệnh càng cao. Áp dụng cách tính số bao thuốc lá (20 điếu) tiêu thụ trong 1 ngày cùng với thời gian (năm) hút cho thấy những người có chỉ số tiêu thụ hơn 20 baonăm (mỗi ngày 1 bao và trong 20 năm) là nhóm có nguy cơ ung thư phổi cũng như các bệnh mạn tính khác cao nhất. Ung thư phổi là nguyên nhẩn hàng đầu của những tử vong do ung thư trên toàn cầu. Triệu chứng sớm có thể là ho, đau ngực, sụt cân, đôi khi ho ra máu. Chẩn đoán được xác định bằng Xquang hoặc CTscanner và sinh thiết phổi (Hình 3, 4).

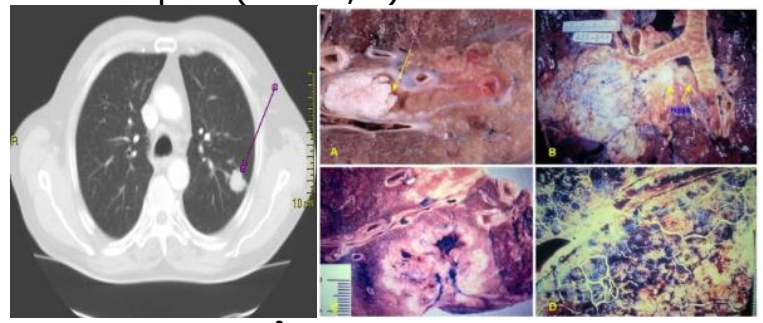

Hình 3. Tồn thương trên CT Scan.

Hinh 4. Tồn thương vi thể Carcinoma phổi

- Bệnh phổi tắc nghẽn mạn tính. Bệnh phổi tẳc nghẽn mạn tính (Chronic Obstructive Pulmonary Disease-COPD) là tình trạng bênh lý biểu hiện bằng triệu chứng hô hấp mạn tính và tắc nghẽn lưu thồng khí không hồi phục hoàn toàn. Nền tảng bệnh học COPD là viêm mạn tính, phá hủy và biến đổi cấu trúc phế quản-phổi có khuynh hướng tiến triển. Thuốc lá là nguyên nhân chủ yếu của COPD, bên cạnh đó còn có sự góp mặt của khói từ nhiên liệu sinh khối (biomass fuels). Biến đổi sâu sắc về cấu trúc hình thái và chức năng lớp biểu mô lông chuyển của niêm mac đường hô hấp do tác động của khói thuốc lá, như đã nói ở phần trên là cơ sở khoa học của bệnh sinh của COPD. Biểu hiện của bệnh có những triệu chứng cơ bản: Ho khạc kéo dài, khó thở tăng dần, nặng ngực, chức năng thông khí bị hạn chế dòng khí thở ra cố định và dai dẳng, nặng dần lên theo thời gian và không hồi phục (chỉ số FEV1/FVC giảm mạnh). Tuy là bệnh của cơ quan hô hấp nhưng ảnh hưởng đến nhiều cơ quan khác do tình trạng thiếu oxi mạn tính, kéo theo các rối loạn chuyển hóa toàn thân. Trong quá trình diễn biến của bệnh, COPD thường xuyên có những đợt cấp (đợt bùng phát - Acute-excacerbations) làm cho bệnh nặng dần lên. Mỗi lần nặng lên như vậy sẽ làm chức năng phổi tồi tệ hơn. Kết cục của bệnh COPD là suy hô hấp man tính, suy tim và tử vong. Theo ước tính của Tố chức $Y$ tế Thế giới COPD gây ra 3,2 triệu ca tử vong mỗi năm (tức là khoảng $5 \%$ tổng số ca tử vong trên toàn cầu mỗi năm). Tại Việt Nam, các ca COPD chiếm tỷ lệ $7,1 \%$ ở nam và $1,9 \%$ ở nữ từ 40 tuổi trở lên.

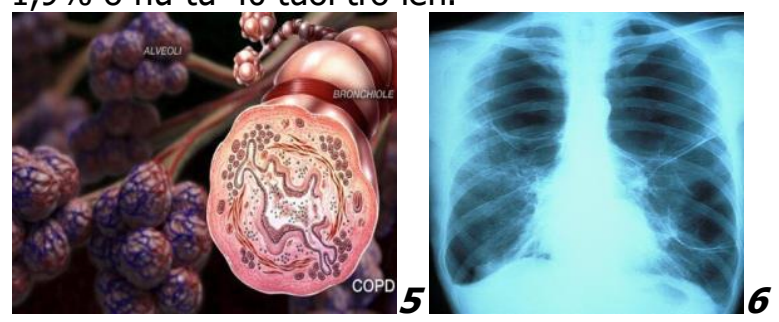

Hình 5. Lòng phếquản bị hẹp lại. Hinh 6. Xquang ngức của COPD

\section{KẾT LUÂNN}

Tác hại của khói thuốc lá tới sức khỏe con người là vấn đề không còn bàn cãi. Bằng những tiến bộ khoa học hiện nay và từ những minh chứng thực tế, các chính sách vĩ mô nhằm hạn chế tác hại của thuốc lá phải được triển khai đồng bộ và quyết liệt từ sản xuất, kinh doanh, tiêu thụ và sử dụng. Không thể đánh đổi lợi nhuận kinh tế và sức khỏe nhiều thế hệ của giống nòi người Việt. Mỗi người hãy tự nói không với thuốc lá, vì sức khỏe của mình, gia đình và cộng đồng.

\section{TÀI LIẸU THAM KHẢO}

1. U.S. Department of Health and Human Services. The Health Consequences of Smoking50 Years of Progress: A Report of the Surgeon General, 2014. Atlanta, GA: U.S. Department of Health and Human Services, Centers for Disease Control and Prevention, National Center for Chronic Disease Prevention and Health Promotion, Office on Smoking and Health, 2014.

2. Thorton, DJ; Rousseau, K; MucGuckin, MA (2008). Structure and function of the polymeric mucins in airways mucus. Annual Review of Physiology. 70 (44): 459-486

3. Atanasova, KR; Reznikov, LR (21 November 2019). Strategies for measuring airway mucus and mucins. Respiratory Research. 20 (1): 261.

4. Yageta $Y$, Ishii $Y$, Morishima $Y$, Masuko $H_{\text {, }}$ Ano $\mathbf{S}$, Yamadori $\mathbf{T}$, Itoh $\mathbf{K}$, Takeuchi $\mathrm{K}$, Yamamoto M, Hizawa N. Role of Nrf2 in host defense against influenza virus in cigarette smokeexposed mice .J Virol. 2011 May; 85(10):4679-90.

5. National Toxicology Program. Tobacco-Related Exposures. In: Report on Carcinogens. Fourteenth Edition. U.S. Department of Health and Human Services, Public Health Service, National Toxicology Program, 2016. 